Ekspansi: Jurnal Ekonomi, Keuangan, Perbankan dan Akuntansi

ISSN (Online): 2580-7668 ISSN (Print): 2085-5230

Vol. 11, No. 2 (November 2019), Hal. 285 - 295

\title{
INFLASI, TINGKAT SUKU BUNGA, DAN KONSUMSI DI PROVINSI ACEH
}

\author{
Hakim Muttaqim ${ }^{1}$, Hamdani ${ }^{2}$, Dasmi Husin ${ }^{3}$ \\ ${ }^{1}$ Fakultas Ekonomi Almuslim, Bireun, Indonesia \\ ${ }^{2,3}$ Politeknik Negeri Lhokseumawe, Lhokseumawe, Indonesia \\ Email Korespondensi: hamdani@pnl.ac.id
}

\begin{abstract}
This study aims to estimate the effect of inflation and interest rates on public consumption in Aceh province in the long term and the short term with the data used are annual data from the above variables starting from 1996 to 2015. The method used is Error Correction Models (ECM). The results of data analysis in this study using Software Eviews 7 shows that inflation has a significant effect on people's consumption in Aceh Province in the long run. In the short term, the effect of inflation on consumption is insignificant and the effect of interest rates is insignificant in the short and long term.
\end{abstract}

Keywords: Consumption, Inflation Rate, Interest Rates, ECM

\begin{abstract}
Abstrak: Penelitian ini bertujuan untuk melihat pengaruh antara inflasi dan tingkat suku bunga terhadap konsumsi masyarakat di provinsi aceh secara jangka panjang dan jangka pendek dengan data yang digunakan adalah data tahunan dari variabel diatas dimulai dari tahun 1996 sampai dengan 2015. Metode yang digunakan adalah Error Correction Models (ECM). Hasil analisis data dalam penelitian ini dengan menggunakan Software Eviews 7 menunjukkan bahwa inflasi berpengaruh secara signifikan terhadap konsumsi masyarakat di Provinsi Aceh secara jangka panjang. Pada jangka pendek, pengaruh inflasi terhadap konsumsi tidak signifikan dan pengaruh suku bunga tidak signifikan di jangka pendek dan jangka panjang.
\end{abstract}

Kata Kunci: Konsumsi, Tingkat Inflasi, Tingkat Suku Bunga, ECM

DOI: $10.35313 /$ ekspansi.v11i2.1627

Riwayat Artikel:

Diterima: $08-11-2019$

Direvisi: $26-11-2019$

Disetujui: $28-11-2019$ 


\section{PENDAHULUAN}

Konsumsi rumah tangga menjadi perhatian mendalam karena konsumsi rumah tangga memberikan sumbangan yang paling besar kepada pendapatan nasional (Madureira, 2007). Konsumsi rumah tangga yang meliputi pembelanjaan rumah tangga pada barang yang tahan lama seperti kendaraan, alat rumah tangga, dan barang tidak tahan lama seperti makanan, dan pakaian serta jasa yang meliputi layanan kesehatan, layanan transportasi, dan layanan lainnya merupakan penyumbang utama pertumbuhan ekonomi di berbagai negara. Namun demikian, tak dapat dipungkiri bahwa terbangunnya suatu indikator konsumsi tidak dapat disamakan antara satu daerah dengan daerah yang lain (Paradiso et al., 2012). Di daerah yang pernah mengalami bencana besar, faktor konsumsi dapat dihambat oleh berbagai-macam faktor terutama yang terkait dengan kerusakan infrastruktur dan distribusi (Solér et al., 2020). Namun di daerah yang tidak pernah mengalami bencana besar, aspek infrastruktur dan distribusi tidak menjadi hambatan konsumsi. Tak dapat dipungkiri bahwa kerusakan infrastruktur dan distribusi dapat merusak kemajuan konsumsi publik. Untuk itulah, faktor-faktor yang dapat mempercepat peningkatan kembali ekonomi konsumsi di kawasan yang pernah mengalami bencana besar tersebut perlu diketahui dengan baik.

Memahami beratnya persoalan ekonomi rumah tangga dan konsumsi pada daerah yang pernah mengalami bencana besar, para ahli menyadari bahwa daerah ini perlu dibangun kembali (Chatterjee and Okazaki, 2018; Karim, 2018; Yao et al., 2019). Sejumlah ahli memberikan sorotan terhadap problematika ekonomi Provinsi Aceh (Heger and Neumayer, 2019; Phelps et al., 2011) dengan mengangkat faktor geografi dan pertumbuan ekonomi. Namun demikian, terkait konteks kebangkitan kembali ekonomi Aceh pasca bencana dan otonomi khusus, hingga saat ini, belum satupun penelitian yang menghubungkan faktor ekonomi makro dan konsumsi di daerah ini. Lebih spesifik lagi, dalam konteks tersebut, hingga saat ini belum ditemukan penelitian yang mengestimasi pengaruh inflasi dan suku bunga terhadap konsumsi di daerah Aceh. Pengembangan pandangan seperti ini didorong oleh Yao et al. (2019). Untuk itulah maka estimasi pengaruh inflasi dan suku bunga terhadap tingkat konsumsi perlu diungkap melalui penelitian ini (Lehrer and Light, 2018; Nagayasu, 2017).

Riset ini bertujuan untuk menguji pengaruh ekonomi makro terhadap tingkat konsumsi publik Aceh. Lebih spesifik lagi, riset ini dilakukan untuk menguji pengaruh suku bunga dan inflasi terhadap tingkat konsumsi publik Aceh. Pemilihan provinsi Aceh didasarkan pada keunikan daerah ini daripada daerah yang lain (Heger and Neumayer, 2019; Phelps et al., 2011). Keunikan spesifik tersebut adalah; (1) provinsi ini baru bangkit pasca kejadian tsunami (Heger and Neumayer, 2019), (2) provinsi Aceh merupakan satu-satunya provinsi di Indonesia yang menerapkan Qanun dan sedikit banyaknya hal tersebut berefek positif terhadap pergerakan ekonomi pasar dan masyarakat (Shah and Lopes Cardozo, 2014), (3) provinsi Aceh mendapatkan otonomi khusus, dan (4) provinsi ini memiliki kearifan lokal yang berbeda dari provinsi yang lain sehingga hal ini turut mencirikhaskan pola konsumsi masyarakat di daerah ini (Shah and Lopes Cardozo, 2014). Berikut gambaran awal tentang inflasi dan suku 
bunga yang dapat diasumsikan pengaruhnya terhadap pergerakan konsumsi masyarakat Aceh.

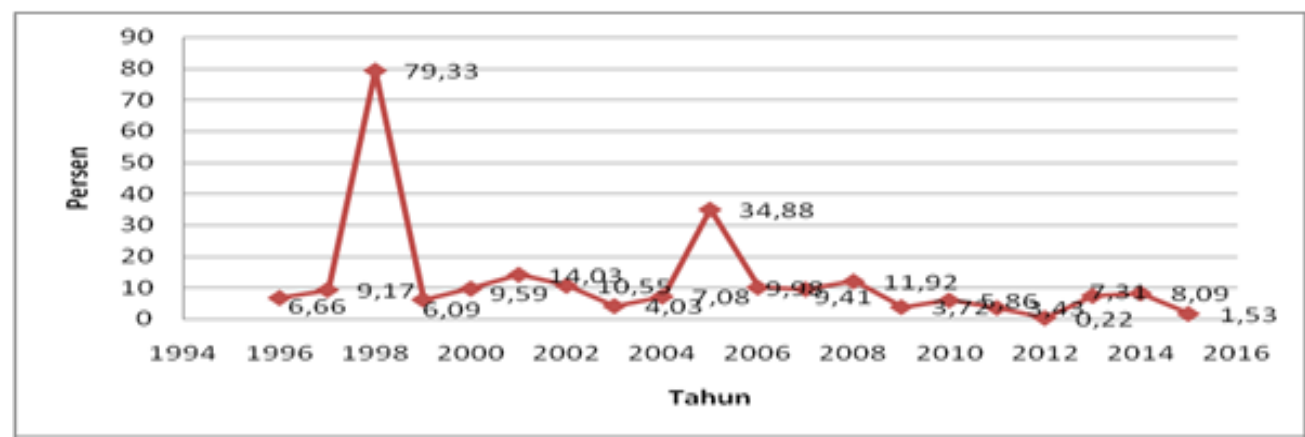

Sumber: Data diolah ( BPS Aceh, 2016)

Gambar 1. Grafik Tingkat Inflasi di Provinsi Aceh Periode 1996-2015

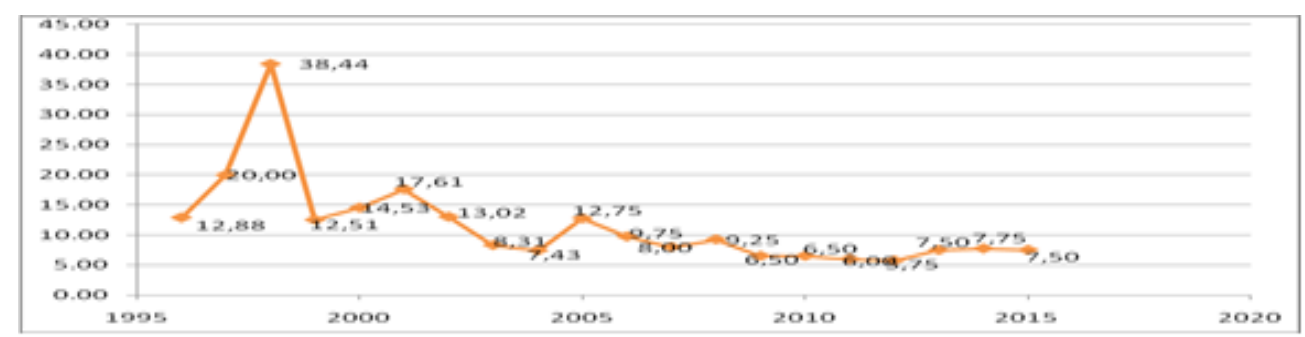

Sumber: Data diolah (Bank Indonesia, 2016)

Gambar 2. Grafik Tingkat Suku Bunga Bank Indonesia Periode 1996-2015

\section{TINJAUAN PUSTAKA}

\subsection{Konsumsi Masyarakat}

Konsumsi rumah tangga adalah pengeluaran yang dilakukan oleh rumah tangga untuk pembelian barang-barang dan jasa-jasa dengan tujuan untuk pemenuhan kebutuhan hidup sehari-hari dalam suatu periode tertentu (Bianchi and Andrews, 2012). Secara makro, peningkatan konsumsi dapat mempengaruhi permintaan terhadap barang dan jasa nasional. Para pakar berbeda pendapat tentang parameter konsumsi makro. Jouini et al. (2013) berpendapat bahwa besaran konsumsi makro tergantung pada besaran pendapatan rumah tangga. Rasio kedua faktor tersebut disebut dengan MPC (marginal propensity to consume) yang artinya adalah semakin tinggi nilai pendapatan rumah tangga maka konsumsi rumah tangga juga semakin tinggi dan begitu juga juga yang terjadi sebaliknya. Sedangkan Alp dan Seven (2019) berpandangan bahwa konsumsi makro tidak cukup diukur menurut pendapatan saja tetapi dapat juga diukur berdasarkan nilai kekayaan yang dimiliki. Tergolong dalam nilai kekayaan tersebut simpanan, investasi, warisan, penyisihan pendapatan, dan lainlain. Pandangan ini menekankan kuatnya domain kekayaan dalam konsumsi publik daripada domain pendapatan. Alasannya adalah bahwa pendapatan lebih spesifik daripada kekayaaan dan di dalam setiap keputusan konsumsi publik selalu mengukur kemampuan konsumsi berdasarkan nilai kekayaannya dan bukan semata nilai pendapatannya. Namun demikian, sekalipun pandangan kedua nampak lebih objektif dari yang pertama, para tokoh memahami bahwa perubahan setiap angka konsumsi selalu seiring seirama dengan pendapatan individu dan negara. Oleh sebab itu, 
pandangan pertama lebih mudah diukur dan diprediksi daripada pandangan yang kedua. Dalam hal inilah maka penelitian ini memilih pandangan pertama yakni konsumsi yang merupakan parameter pendapatan publik sebagai parameter konsumsi.

Ditinjau secara geografis, teori konsumsi makro dapat dibedakan berdasarkan perkotaan dan pedesaan (Tesfaye and Tirivayi, 2020). Konsumsi publik perkotaan ditopang oleh kuatnya akses distribusi, mapannya infrastruktur, lengkapnya sumberdaya, majunya teknologi perdagangan, dan variatifnya ruang pasar (Thye Goh Tiong, 2014). Sedangkan konsumsi publik pedesaan selalu mengalami yang peristiwa sebaliknya. Di wilayah pedesaan, atau dapat pula disebut daerah, konsumsi publik selalu dihambat oleh lemahnya aksesibilitas distribusi, lemahnya infrastruktur, kurangnya sumberdaya, tidak lengkapnya teknologi dagang, dan terbatasnya ruang pasar. Para pakar (Tesfaye and Tirivayi, 2020; Wang et al., 2009) menilai bahwa sekalipun wilayah pedesaan atau daerah lebih tertinggal dalam aspek kemampuan konsumsi daripada perkotaan namun di beberapa negara wilayah pedesaan atau daerah mampu berdaya saing dengan kota. Beberapa aspek makro sangat mendukung kemajuan konsumsi tersebut. Penelitian ini berupaya mempertegas pandangan tersebut, khususnya dalam objek yang sedang diamati oleh penelitian ini.

\subsection{Inflasi}

Inflasi adalah kenaikan tingkat harga yang terjadi secara umum dan tiada henti selama periode waktu tertentu (Paradiso et al., 2012). Kenaikan harga yang terjadi secara spesifik pada satu atau dua barang saja tidak dapat didefinsikan inflasi, kecuali jika naiknya harga itu terjadi secara luas dan berefek terhadap harga komoditaskomoditas yang lain (Madureira, 2007). Para pakar (Abaidoo Rexford, 2016; Nagayasu, 2017) membedakan inflasi peningkatan permintaan (demand pull inflation) dan inflasi peningkatan biaya produksi (cost pull inflation). Inflasi yang pertama merupakan kejadian inflasi yang diakibatkan oleh meningkatnya permintaan pada macam barang atau jasa tertentu. Dalam kondisi ini, terjadinya peningkatan permintaan barang/jasa terjadi secara umum (aggregate demand). Inflasi pada jenis ini terjadi karena peningkatan belanja negara, peningkatan permintaan barang yang akan diekspor, dan peningkatan barang yang akan dijual ke pihak swasta. Sedangkan inflasi yang kedua diartikan peningkatan harga akibat lonjakan biaya produksi. Pencetus utama inflasi ini adalah kenaikan harga bahan-bahan baku seperti bahan bakar minyak dan bahan-bahan produksi. Para pakar mengakui bahwa kedua macam inflasi ini selalu mewarnai fluktuasi inflasi di berbagai negara dunia. Oleh karena representatifnya bentuk inflasi terhadap suasana inflasioner di beberapa negara, maka penelitian ini mengasosiasikan bentuk fluktuasi inflasi pada objek riset berdasarkan kedua macam inflasi tersebut.

Riset terdahulu (Nagayasu, 2017) telah membuktikan bahwa inflasi berperan dalam perubahan tingkat konsumsi publik. Dengan kata lain, inflasi berpengaruh secara signifikan terhadap konsumsi. Jika inflasi meningkat, maka kemampuan konsumsi publik menurun dan jika inflasi menurun maka kemampuan konsumsi publik menjadi lebih baik (Čiplienè et al., 2019). Oleh karena itulah maka hubungan inflasi dan konsumsi selalu negatif. Oleh karena jelasnya hubungan inflasi dengan 
konsumsi, maka riset ini mengasumsikan bahwa perubahan tingkat inflasi dapat mempengaruhi laju perkembangan konsumsi. Atas dasar itulah, maka hipotesis di bawah ini disusun.

$\mathrm{H}_{1}$ : Inflasi berpengaruh terhadap Konsumsi Masyarakat di Provinsi Aceh

\subsection{Suku bunga}

Suku bunga ialah nilai persentase yang dihitung berdasarkan nilai pokok pinjaman yang wajib dibayar oleh pihak debitur dalam suatu periode tertentu dan diterima oleh pihak kreditur sebagai keuntungan atau imbal jasa (Soon et al., 2017). Suku bunga digunakan sebagai pengendali kehidupan ekonomi suatu negara. Level suku bunga ditentukan oleh pemerintah dengan maksud untuk menjaga kesinambungan ekonomi suatu negara (Lehrer and Light, 2018). Penetapan suku bunga berdasarkan suatu level tertentu sangat penting untuk mempegaruhi investor yang mengharapkan perolehan investasi yang lebih tinggi. Dilihat dari jenisnya, para pakar (Soon et al., 2017) membagi suku bunga menjadi dua yakni suku bunga nominal dan suku bunga riil. Suku bunga nominal ialah level bunga yang ditetapkan dalam nilai uang, sehingga suku bunga ini dapat diketahui atau dibaca secara umum. Suku bunga ini menampakkan sejumlah nilai mata uang untuk satu nilai mata uang (misalnya dolar atau rupiah) yang diinvestasikan. Sedangkan suku bunga riil ialah level bunga yang dikoreksi atas peristiwa inflasi dan diartikan sebagai tingkat bunga nominal dikurangi dengan suatu tingkat inflasi. Oleh karena dinamisnya bentuk suku bunga riil, maka suku bunga ini akan selalu berubah seiring dengan perubahan kondisi ekonomi dan inflasi. Untuk itulah maka penelitian ini menggunakan data suku bunga riil sebagai acuan untuk membaca perubahan situasi ekonomi objek penelitian yang sedang diamati.

Literatur-literatur terdahulu (Hahm, 1998; Lehrer and Light, 2018; Nayeem et al., 2009) telah menguji pengaruh suku bunga terhadap konsumsi. Semua literatur tersebut menampakkan pengaruh yang signifikan atas hubungan suku bunga dan konsumsi tersebut. Jelasnya pengaruh tersebut ditandai oleh perubahan reaksi masyarakat atas setiap perubahan basis poin suku bunga bank sentral. Jika suku bunga bank sentral meningkat, misalnya dalam suku bunga deposito, maka masyarakat bereaksi meningkatkan simpanan deposito di bank, begitu juga jika sebaliknya. Dalam suku bunga kredit, apabila bank sentral menurunkan suku bunga, maka publik akan berbondong-bondong mengajukan pinjaman kepada bank (Soon et al., 2017). Lebih spesifik lagi dalam sektor rumah tangga, khususnya kredit perumahan, jika suku bunga perumahan rendah maka minat masyarakat untuk mengajukan kredit perumahan menjadi lebih tinggi dan begitu juga sebaliknya (Lehrer and Light, 2018). Oleh karena jelasnya dan kuatnya pengaruh suku bunga terhadap konsumsi, maka penelitian ini mengajukan hipotesis di bawah ini.

$\mathrm{H}_{2}$ : Suku Bunga berpengaruh terhadap Konsumsi Masyarakat di Provinsi Aceh

\section{METODE PENELITIAN}

Data yang digunakan dalam penelitian ini adalah data sekunder yang didapatkan dari Badan Pusat Statistik Provinsi Aceh dan Bank Indonesia. Data tersebut antara 
lain: (1) nilai konsumsi masyarakat Provinsi Aceh dari tahun 1996-2015, (2) inflasi Provinsi Aceh tahun 1996-2015, dan (3) suku bunga Bank Indonesia tahun 1996-2015.

Metode yang digunakan dalam penelitian ini adalah kuantitatif. Objek yang ditetapkan oleh peneliti dalam penelitian ini adalah inflasi dan tingkat suku bunga yang mempengaruhi konsumsi di Provinsi Aceh, adapun subjek dalam penelitian ini adalah Provinsi Aceh secara jangka panjang dan jangka pendek. Dalam melihat pengaruh variabel inflasi dan suku bunga terhadap konsumsi masyarakat, penelitian ini menggunakan model regresi dengan metode Error Correction Mechanism (ECM) untuk melihat fluktuasi dalam jangka pendek.

Untuk menjawab hipotesis penelitian faktor-faktor yang mempengaruhi konsumsi di Provinsi Aceh, maka variabel-variabel yang akan dianalisis yaitu Konsumsi, PDRB, Suku Bunga dan Inflasi. Adapun model yang digunakan dari regresi linear berganda menurut (Sanusi, 2011) yaitu: $\hat{\boldsymbol{Y}}=\boldsymbol{\beta} 0+\boldsymbol{\beta} 1 \boldsymbol{X} 1+\boldsymbol{\beta} 2 \boldsymbol{X} 2+\boldsymbol{\varepsilon}$

Dimana:

$\hat{\boldsymbol{Y}}=$ Konsumsi

$\boldsymbol{\beta} \boldsymbol{O}=$ Koefisien Konstanta

$\boldsymbol{X}_{I}=$ Inflasi

$$
\begin{aligned}
& \mathbf{X}_{\mathbf{2}}=\text { Suku Bunga } \\
& \boldsymbol{\varepsilon}=\text { Koefisien Error (Variabel Pengganggu) }
\end{aligned}
$$

\section{HASIL DAN PEMBAHASAN}

\subsection{Uji akar-akar unit}

Data yang diteliti dalam penelitian ini adalah data runtun waktu (time series). Data yang diobservasi harus bersifat stasioner. Pada penelitian ini, uji stasioner dilakukan dengan uji akar unit menggunakan Augmented Dickey Fuller (ADF) test. Berdasarkan Gambar 1, variabel-variabel obeservasi tidak stasioner di level, hal ini ditunjukan oleh nilai probabilitas yang lebih dari alpha $5 \%$. Karena variabel-variabel yang diobservasi tidak stasioner di level, maka selanjutnya dilakukan pengujian derajat intergrasi. Uji intergrasi dilakukan pada ordo atau differencing beberapa variabel-variabel tersebut

\begin{tabular}{|c|c|c|c|c|}
\hline \multicolumn{3}{|c|}{ Method } & Statistic & Prob. ${ }^{* *}$ \\
\hline \multicolumn{3}{|c|}{ ADF - Fisher Chi-square } & 30.2097 & 0.0000 \\
\hline \multicolumn{3}{|c|}{ ADF - Choi Z-stat } & -2.74656 & 0.0030 \\
\hline \multicolumn{5}{|c|}{$\begin{array}{l}\text { ** Probabilities for Fisher tests are computed using an asymptotic Chi } \\
\text {-square distribution. All other tests assume asymptotic normality. }\end{array}$} \\
\hline \multicolumn{5}{|c|}{ Intermediate ADF test results UNTITLED } \\
\hline Series & Prob. & Lag & Max Lag & Obs \\
\hline$\overline{\mathrm{Y}}$ & 0.9566 & 0 & 4 & 19 \\
\hline $\mathrm{X} 1$ & 0.0001 & 2 & 4 & 17 \\
\hline X2 & 0.0033 & 0 & 4 & 19 \\
\hline
\end{tabular}
sama-sama stasioner.

Sumber:data olahan (Output Eviews7)

Gambar 3. Uji ADF - Fisher Chi-square

Dari hasil Uji ADF - Fisher Chi-square menunjukan probabilitas data 0,0030. $(<5 \%)$. Hal ini menunjukkan variabel sudah stasioner. Lag maksimum untuk Y dan X yang diambil adalah 4 . Lag 0 menunjukkan periode penelitian tahun sekarang (current 
year). sedangkan $X_{1}$ leg nya 2 maka dua data harus di elimmenasi 2 data (dari 19 menjadi 17).

\begin{tabular}{|c|c|c|c|c|}
\hline \multicolumn{3}{|l|}{ Method } & Statistic & Prob. ${ }^{* *}$ \\
\hline \multicolumn{3}{|c|}{ ADF - Fisher Chi-square } & 80.8667 & 0.0000 \\
\hline \multicolumn{3}{|c|}{ ADF - Choi Z-stat } & -7.83791 & 0.0000 \\
\hline \multicolumn{5}{|c|}{$\begin{array}{l}\text { ** Probabilities for Fisher tests are computed using an asymptotic Chi } \\
\text {-square distribution. All other tests assume asymptotic normality }\end{array}$} \\
\hline \multicolumn{5}{|c|}{ Intermediate $\mathrm{ADF}$ test results $\mathrm{D}$ (UNTITLED) } \\
\hline \multirow[b]{2}{*}{ Series } & \multicolumn{4}{|c|}{ Max } \\
\hline & Prob. & Lag & Lag & Obs \\
\hline $\mathrm{D}(\mathrm{Y})$ & 0.0005 & 0 & 3 & 18 \\
\hline $\mathrm{D}(\mathrm{X} 1)$ & 0.0000 & 1 & 3 & 17 \\
\hline $\mathrm{D}(\mathrm{X} 2)$ & 0.0000 & 0 & 3 & 18 \\
\hline
\end{tabular}

Sumber: Data Olahan (Output Eviews7).

Gambar 4. Uji Derajat Integrasi

Karena pada differencing level variabel y belum stasioner maka dilakukan differencing level 1 . Setelah di differencing level 1 nilai probabilitas semua variabelvariabel tersebut telah dibawah atau kurang dari alpha 5\%, artinya variabel-variabel tersebut stasioner di differincng level 1.

\begin{tabular}{lcccc}
\hline Variable & Coefficient & Std. Error & t-Statistic & Prob. \\
\hline X1 & -617886.4 & 175093.3 & -3.528898 & 0.0026 \\
X2 & 148762.3 & 74511.60 & 1.996499 & 0.0622 \\
C & 12103267 & 1472708. & 8.218376 & 0.0000 \\
\hline \hline R-squared & 0.496967 & Mean dependent var & 6747641. \\
Adjusted R-squared & 0.437787 & S.D. dependent var & 3786656. \\
S.E. of regression & 2839268. & Akaike info criterion & 32.69347 \\
Sum squared resid & $1.37 \mathrm{E}+14$ & Schwarz criterion & 32.84283 \\
Log likelihood & -323.9347 & Hannan-Quinn criter. & 32.72263 \\
F-statistic & 8.397506 & Durbin-Watson stat & 0.530674 \\
Prob(F-statistic) & 0.002908 & & \\
\hline \hline Sumber: data olahan ( Output eviews 7) & \\
\multicolumn{4}{c}{ Gambar 5. Estimasi Model Jangka Panjang }
\end{tabular}

Nilai variabel $\left(\mathrm{X}_{1}\right)$ menunjukkan hasil koefisien yang terbalik yakni -617886,6 dan t tabel -3,52., namun memiliki nilai probalbility sebesar 0,0026. Berbeda halnya dengan nilai $\mathrm{X}_{2}$ yang menunjukkan arah yang positif dan nilai probalility yang sedikit menguat. Jika dikomperatifkan dengan R-Squared senilai 0,49 maka dapat diketahui kereratan dua variabel independen tersebut rendah. Hanya sebesar 49\%, sedangkan kecepatan penyesuaiannya variabel sebesar $43,7 \%$.

\begin{tabular}{lllll}
\hline \hline Variable & Coefficient & Std. Error & t-Statistic & Prob. \\
\hline \hline C & 588977.2 & 172722.5 & 3.409962 & 0.0039 \\
D(X1) & -7118.296 & 69578.96 & -0.102305 & 0.9199 \\
D(X2) & 4646.729 & 21074.65 & 0.220489 & 0.8285 \\
RES(-1) & -0.047989 & 0.074177 & -0.646949 & 0.5274 \\
\hline \hline R-squared & 0.041071 & Mean dependent var & 602966.1 & \\
Adjusted R-squared & -0.150715 & S.D. dependent var & 692493.6 & \\
S.E. of regression & 742847.4 & Akaike info criterion & 30.05903 & \\
Sum squared resid & $8.28 \mathrm{E}+12$ & Schwarz criterion & 30.25786 & \\
Log likelihood & -281.5608 & Hannan-Quinn criter. & 30.09268 & \\
F-statistic & 0.214150 & Durbin-Watson stat & 2.345118 & \\
Prob(F-statistic) & 0.885035 & & & \\
\hline \hline
\end{tabular}

Sumber: data olahan (output eviews 7)

Gambar 6. Estimasi Model Jangka Pendek 
Dari tabel diatas dapat dijelaskan bahwa inflasi dan suku bunga jangka pendek tidak mempengaruhi tingkat konsumsi masyarakat (Y). Artinya kenaikan harga barang dalam waktu terbatas (dekat) tidak mempengaruhi pola konsumsi masyarakat Aceh. Tingkat inflasi mempengaruhi konsumsi masyarakat secara jangka panjang. Nilai-nilai yang ditunjukkan mengindikasikan bahwa pola konsumsi masyarakat akan terus berubah signifikan jika tingkat inflasi bergerak naik.

\subsection{PEMBAHASAN}

Berdasarkan tahapan tahapan dari pengolahan dengan Error Corection Model (ECM) maka didapatlah 2 persamaan yaitu, jangka pendek daan jangka panjang sehingga dapat dipaparkan sebagai berikut:

\section{a. jangka panjang}

$$
\mathrm{Y}_{\mathrm{t}}=12103267-617886.4 \mathrm{X} 1_{\mathrm{t}}+148762.3 \mathrm{X} 2_{\mathrm{t}}
$$

Dari persamaan diatas dapat dilihat bahwa inflasi dan suku bunga berpengaruh secara signifikan

\section{b. Jangka pendek}

$\mathrm{Yt}_{\mathrm{t}=588977.2-7118.296 \times 1+4646.729 \times 2}-0.047989$ res $_{\mathrm{t}-1}$

Dari persamaan diatas dapat dilihat bahwa inflasi dan suku bunga tidak berpengaruh secara signifikan dan berdasarkan nilai speed of adjustment, ada sebesar 0.048 atau $4.8 \%$ ketidakseimbangan, pada variable inflasi dan suku bunga yang tidak bepengaruh terkoreksi setiap periodenya.

\subsection{DISKUSI}

Riset ini berhasil mengungkap kekuatan hubungan inflasi dan suku bunga dengan konsumsi melalui analisis ECM. Temuan statistik menunjukkan bahwa dalam jangka panjang, inflasi berpengaruh terjadap konsumsi sedangkan suku bunga tidak mempengaruhi konsumsi. Di samping itu, dalam jangka pendek, baik inflasi maupun suku bunga keduanya tidak mempengaruhi konsumsi. Sekalipun tidak sepenuhnya berpengaruh, temuan ini mendukung pandangan Nagasayu (2017) dan Lehrer dan Light (2018) yang menemukan terdapatnya hubungan antara aspek makro terhadap perubahan konsumsi publik, setidaknya dari aspek inflasi jangka panjang. Temuan ini juga mendukung pandangan Yao et al. (2019) mengenai pentingnya aspek pemenuhan kebutuhan publik sebagai domain pembangunan kembali daerah yang pernah mengalami bencana besar, setidaknya dari aspek pengendalian inflasi jangka panjang. Tidak signifikannya pengaruh inflasi di jangka panjang dan suku bunga di jangka pendek dan jangka panjang menunjukkan bahwa konsumsi pada masyarakat Aceh tidak semata dibangun berdasarkan perubahan inflasi dan kebijakan suku bunga melainkan terdapatnya faktor lain yang belum terungkap. Berarti, bagi masyarakat Aceh, harga dan suku bunga yang cenderung berubah-ubah tidak berefek langsung terhadap fluktuasi konsumsi. 
Pada perspektif manajerial, riset ini berimplikasi terhadap pembangunan ekonomi konsumsi masyarakat provinsi Aceh. Ada dua hal yang perlu dilakukan oleh pemerintah provinsi Aceh dalam upaya peningkatan konsumsi publik. Pertama, inflasi jangka panjang merupakan faktor yang dapat mempengaruhi konsumsi publik Aceh. Terkait dengan hal ini, pihak provinsi dan bank sentral perlu mewaspadai perubahan harga di masa mendatang melalui penguatan suplai bahan makanan, penguatan pasokan input industri, peredaran uang, dan hal-hal lain yang menaikan inflasi jangka panjang. Kedua, oleh karena suku bunga tidak berpengaruh terhadap konsumsi di jangka pendek dan jangka panjang, serta inflasi tidak berpengaruh terhadap konsumsi di jangka pendek, berarti ada faktor lain yang dapat mempengaruhi konsumsi publik. Untuk itulah, pemerintah provinsi perlu mengelaborasi peningkatan konsumsi melalui faktor-faktor lain yang bersifat makro maupun mikro.

\section{PENUTUP}

Berdasarkan hasil pembahasan, dapat disimpulkan bahwa inflasi hanya berpengaruh terhadap konsumsi masyarakat Aceh pada jangka panjang. Sedangkan inflasi jangka pendek dan suku bunga jangka pendek dan jangka panjang tidak berpengaruh terhadap konsumsi. Dengan demikian, riset ini telah berkontribusi dalam mengungkap kedudukan hubungan semua variabel tersebut dengan baik.

Walaupun telah berhasil mengungkapkan hubungan inflasi dan suku bunga dengan konsumsi masyarakat Aceh, riset ini memiliki sejumlah kelemahan. Pertama, pada riset ini tidak semua variabel menunjukkan pengaruh yang signifikan, khususnya pengaruh Inflasi terhadap konsumsi di jangka pendek, serta pengaruh suku bunga terhadap konsumsi masyarakat di jangka panjang dan jangka pendek. Untuk itulah, disarankan bagi peneliti selanjutnya untuk menggali faktor-faktor lain yang dapat mempengaruhi konsumsi publik Aceh. Kedua, riset ini hanya dilakukan di Aceh. Untuk menghasilkan temuan yang lebih baik, disarankan peneliti selanjutnya untuk menguji konsumsi publik pada wilayah yang lebih luas.

\section{DAFTAR PUSTAKA}

Abaidoo Rexford, 2016. Inflation expectations, economic policy ambiguity and microlevel consumer behavior. Journal of Financial Economic Policy 8, 377-395. https://doi.org/10.1108/JFEP-12-2015-0074

Alp, E., Seven, Ü., 2019. The dynamics of household final consumption: The role of wealth channel. Central Bank Review 19, 21-32. https://doi.org/10.1016/j.cbrev.2019.03.002

Bianchi, C., Andrews, L., 2012. Risk, trust, and consumer online purchasing behaviour: a Chilean perspective. International Marketing Review 29, 253-275. https://doi.org/10.1108/02651331211229750

Chatterjee, R., Okazaki, K., 2018. Household Livelihood Recovery after 2015 Nepal Earthquake in Informal Economy: Case Study of Shop Owners in Bungamati. Procedia Engineering 212, 543-550. https://doi.org/10.1016/j.proeng.2018.01.070 
Čiplienè, A., Gurevičius, P., Janulevičius, A., Damanauskas, V., 2019. Experimental validation of tyre inflation pressure model to reduce fuel consumption during soil tillage. Biosystems Engineering 186, 45-59. https://doi.org/10.1016/j.biosystemseng.2019.06.023

Hahm, J.-H., 1998. Consumption adjustment to real interest rates: Intertemporal substitution revisited. Journal of Economic Dynamics and Control 22, 293-320. https://doi.org/10.1016/S0165-1889(97)00053-5

Heger, M.P., Neumayer, E., 2019. The impact of the Indian Ocean tsunami on Aceh's long-term economic growth. Journal of Development Economics 141, 102365. https://doi.org/10.1016/j.jdeveco.2019.06.008

Jouini, E., Napp, C., Nocetti, D., 2013. The marginal propensity to consume and multidimensional risk. Economics Letters 119, 124-127. https://doi.org/10.1016/j.econlet.2013.02.002

Karim, A., 2018. The Household Response to Persistent Natural Disasters: Evidence from Bangladesh. World Development 103, 40-59. https://doi.org/10.1016/j.worlddev.2017.10.026

Lehrer, E., Light, B., 2018. The effect of interest rates on consumption in an income fluctuation problem. Journal of Economic Dynamics and Control 94, 63-71. https://doi.org/10.1016/j.jedc.2018.07.004

Madureira, L., 2007. The ex ante real rate and inflation premium under a habit consumption model. Journal of Empirical Finance 14, 355-382. https://doi.org/10.1016/j.jempfin.2006.09.003

Nagayasu, J., 2017. Inflation and consumption of nontradable goods: Global implications from regional analyses. International Review of Economics \& Finance 48, 478-491. https://doi.org/10.1016/j.iref.2017.01.004

Nayeem, O., Shiliwala, M., Shiliwala, W., 2009. A CONFLICT OF INTEREST: ISLAMIC HOME FINANCING IN AMERICA. Economic Affairs 29, 22-27. https://doi.org/10.1111/j.1468-0270.2009.01889.x

Paradiso, A., Casadio, P., Rao, B.B., 2012. US inflation and consumption: A long-term perspective with a level shift. Economic Modelling 29, 1837-1849. https://doi.org/10.1016/j.econmod.2012.05.037

Phelps, N.A., Bunnell, T., Miller, M.A., 2011. Post-disaster economic development in Aceh: Neoliberalization and other economic-geographical imaginaries. Geoforum 42, 418-426. https://doi.org/10.1016/j.geoforum.2011.02.006

Shah, R., Lopes Cardozo, M., 2014. Education and social change in post-conflict and post-disaster Aceh, Indonesia. International Journal of Educational Development 38, 2-12. https://doi.org/10.1016/j.ijedudev.2014.06.005

Solér, C., Koroschetz, B., Salminen, E., 2020. An infrastructural perspective on sustainable consumption - Activating and obligating sustainable consumption through infrastructures. Journal of Cleaner Production 243, 118601. https://doi.org/10.1016/j.jclepro.2019.118601

Soon, S.-V., Baharumshah, A.Z., Mohamad Shariff, N.S., 2017a. The persistence in real interest rates: Does it solve the intertemporal consumption behavior puzzle? 
Journal of International Financial Markets, Institutions and Money 50, 36-51. https://doi.org/10.1016/j.intfin.2017.08.009

Soon, S.-V., Baharumshah, A.Z., Mohamad Shariff, N.S., 2017b. The persistence in real interest rates: Does it solve the intertemporal consumption behavior puzzle? Journal of International Financial Markets, Institutions and Money 50, 36-51. https://doi.org/10.1016/j.intfin.2017.08.009

Tesfaye, W., Tirivayi, N., 2020. Crop diversity, household welfare and consumption smoothing under risk: Evidence from rural Uganda. World Development 125, 104686. https://doi.org/10.1016/j.worlddev.2019.104686

Thye Goh Tiong, 2014. Exploring a consumption value model for Islamic mobile banking adoption. Journal of Islamic Marketing 5, 344-365. https://doi.org/10.1108/JIMA-08-2013-0056

Wang, X., Liu, J., Xin, X., 2009. China's rural poverty line and the determinants of rural poverty. China Agricultural Economic Review 1, 283-300. https://doi.org/10.1108/17561370910958864

Yao, D., Xu, Y., Zhang, P., 2019. How a disaster affects household saving: Evidence from China's 2008 Wenchuan earthquake. Journal of Asian Economics 64, 101133. https://doi.org/10.1016/j.asieco.2019.101133 